\title{
Archetypal Anxieties in Stanley Kubrick's The Shining
}

\author{
Ya-huei Wang \\ Department of Applied Foreign Languages, Chung-Shan Medical University, \\ Department of Medical Education, Chung Shan Medical University Hospital, \\ No. 110, Sec. 1, Jian-Koa N. Road, Taichung (402), Taiwan \\ e-mail: huncliao@ms43.hinet.net
}

\begin{abstract}
The study intends to study the archetypal anxieties in Stanley Kubrick's (1980) The Shining, which can be interpreted as Danny's journey for the completion of his individualization process. In his individualization process, Danny has to go through the anxieties often seen in fairytales, such as separation anxieties, authoritarian anxieties, Oedipal rivalry anxieties, and sexual anxieties, in order to acquire his autonomy. The Overlook Hotel becomes symbolic of collective human evil, being charged with evil spirits. Only those who refused to identify themselves as victims would escape from the evil history of the hotel and would not be transformed into a homicidal maniac, pouring their anger to their families.
\end{abstract}

Key words: anxiety, initiation, individualization, autonomy

Based on Stephen King's (1977) best-selling novel, Stanley Kubrick's The Shining (1980) employs the archetypal narrative pattern of separationinitiation-return in Danny's experience in the Overlook Hotel. Danny's journey in the Overlook Hotel can be interpreted as a journey for the completion of his individualization process. In this individualization process, Danny encounters psychological anxieties concerning his childhood relationship to his parents and other family members. These are anxieties often seen in fairytales and include separation anxieties (feelings of being rejected), authoritarian anxieties (feelings of being oppressed), Oedipal rivalry anxieties, and sexual anxieties to acquire his autonomy (Jung, 1990). For Danny, then, his experiences in the Overlook Hotel are an attempt to acquire his autonomy.

If children are born and raised by two parents, the Oedipus complex is unavoidable during the process of individualization (Freud, 1955). When 
Danny was younger, his father, Jack, dislocated his shoulder in a fit of rage. Since that time, he has been afraid of and detached from his father, and become closer to his mother, Wendy. Shadowed by this dislocation, a kind of castration anxiety, Danny is forced to invent a double, Tony, to speak out for and protect the true Danny (Holland-Toll, 1999).

After being dislocated by his father, in order to complete his identity development, Danny looks to Dick Hollorann as a good father image. The bad father image is Danny's real father, Jack. Dick Hollorann shares Danny's psychic abilities - the shining — and warns him of the dangers hidden in the Overlook Hotel (Hoile, 1984). It is with the assistance of Dick as a good father image that Danny can fight against the destructive part of the bad father.

In the Oedipus conflict, the child wishes his parent-competitor out of the way to win the other parent's complete attention. In an extreme case, the child may wish his parent-competitor to die (Freud, 1958, p. 232). In The Shining, Danny's latent death-wish against Jack (the bad father) becomes reality in the death of Dick Hollorann (the good father).

When children experience Oedipal anxiety, they may not only split their parent into two figures, but also split themselves into two figures as a protective move (Freud, 1955). After Jack dislocates Danny's arm (symbolic of castration), Danny creates an imaginary guardian angel to watch over him. Tony, who lives in Danny's mouth, talks through Danny's finger. With Tony's help, Danny manages the dangerous forces in the Overlook Hotel. Moreover, with the creation of a doubling and interchangeable self, Danny can project his negative thoughts about his father onto someone else.

In Jung's words, the behavior of projection as an "unconscious, automatic process whereby a content that is unconscious to the subject transfers itself to an object, so that it seems to belong to that object. The projection ceases the moment it becomes conscious, that is to say when it is seen as belonging to the subject” (Jung, 1990, p. 60). Danny's shining can be regarded as neuroses. According to Jung (1990), neuroses result from a person's failure to confront and accept some part of his/her archetypal unconscious. Instead of integrating this unconscious part to his/her consciousness, the neurotic individual insists on projecting it onto some other person or object. The dislocation accident causes Danny to have the anxiety of being annihilated. However, in order to protect himself, he projects all the destructive thoughts about his father onto Tony. 
Jack, for his part, is stuck in the Oedipal triangle (Hoile, 1984), and is unable to enjoy his son as he grows and begins to surpass him. In fact, Jack seems quite jealous of Danny. Jack's alcoholism had strained his relationship with his wife and son, and when he accidentally dislocated Danny's shoulder in a drunken rage, he lost Wendy's trust. Wendy and Danny became closer because of the incident and Jack gets anxious that his son would replace him in his wife's affections.

Jack's original intentions of taking the position at the Overlook Hotel were to reaffirm his role as father and husband. However, the confinement causes him to suffer from feelings of isolation and boredom. He becomes burdened by writer's block and jealous of Danny's shining. "Shining” is uncanny psychic power, and with it Danny can see through the past and future and "read" other people (Smith, 1997). Although Danny's power is not creative, it has strong correlations with Jack's talents as a writer. The creative act involves moving backward and forward through time, and the writer's talent is one of insight into the lives of others. Danny's shining, then, is a symbol for writing, and Danny's possession of it and Jack's lack of it are placed in stark contrast. Jack becomes afraid of being thought worthless by his family and of losing their love, but he also fears Danny overtaking him as the powerful male of the household (Caldwell \& Umland, 1986).

Jack's anxiety is reflected in his nightmare. The formation of dreams can be provoked in two different ways - either through the id or through the ego. Dreams can be formed through the id, which is restrained while one is awake but liberated during sleep. On the other hand, dreams can be the result of desires left over from daily life that are reinforced unconsciously during sleep. Through dreams, a sense of satisfaction or a resolution of a conflict can be realized (Freud, 1999). Jack's nightmare can be analyzed through Freud's supposition that parents are inclined to kill their children because they are afraid of the rivalry they will come to present. Not being able to analyze his nightmare, Jack fails to face his unconscious and gain a better understanding of himself. Instead of admitting his latent wish to punish his family when they are out of line, Jack constrains his unconsciousness, finally becoming crippled.

In the same way that he cannot face his nightmares, Jack cannot face the reality of Room 237. This room is symbolic of Jack's fear of aging. Fairytales often end with the phrase "They lived happily ever after" (Zipes, 1994; McGlathery, 1993). However, human beings are mortal and can 
never know "ever after". Notably, there is a scene in the film in which twin sisters ask Danny to play with them "for ever and ever and ever." Later, while Danny is sitting uncomfortably in Jack's lap, Jack tells Danny that he wants to stay at the Overlook "for ever and ever and ever." These fantasies about eternal life draw Jack back to his unconsciousness, because, based on Freud's supposition (1955), only the unconscious is eternal. Jack's ignorance of his unconscious makes him unable to encounter and know it, and this is what ultimately leads to his self-destruction.

Room 237 also represents Jack's sexual desire (Caldwell \& Umland, 1986). For Jack, the woman in the bathtub-seductive, beautiful, dangerous - symbolizes his latent wish to have a substitute for Wendyfaithful, understanding, plain. Most men desire to have sexual relationships with women other than their wives, but Jack's problem lies in that he cannot face his repressed desire. He denies it, not knowing that the neglect of repressed sexuality may simply make it stronger.

Room 237 has sexual connotations for Danny as well. His decision to enter it represents Danny's psychic and sexual awakening, leading him to full complexity. Early in the film, Dick Hollorann warns Danny never to enter Room 237. He does not say what is behind the door, but the forbidden room is often representative of sexual knowledge in fairytales. According to Bettelheim (1977), a locked room often refers to the female sexual organs, and turning the lock of the door symbolizes intercourse. Furthermore, the key that opens the door to a forbidden room is often associated with the male sexual organ (pp. 300-301). As Alice's key admits her to the world of Wonderland, Danny opens up a world of sexual desire and knowledge, thus driving him toward self-realization.

According to Freud (1955), in the movement of a boy's progress towards heterosexuality, he has to pass through the stage of the Oedipal conflict in which he homoerotically identifies with his father. He then turns away from his father to find his own heterosexual role. Without identification with his father, Danny may take an abnormal identification with his mother and become a homosexual. Danny's painful sexual initiation in Room 237 is reminiscent of Freud's theory that a child must see the sexual act as disgusting as long as his sexual desire is attached to his parent in order not to violate the incest taboo and destabilize the family.

There is a series of symbolic numbers (Jung, 1990) in Room 237. The number two can signify a couple or a marriage, and the number three is reminiscent of the threesome of snake, Eve, and Adam which initiates 
carnal knowledge. The number three represents sex in the unconscious, as each sex has three visible sex characteristics: in males, penis and the two testes; in females, vagina and the two breasts. Three also refers to the male principle, and four to the female principle. Both the number seven $(3+4)$ and the number twelve $(2+3+7)$ indicate the completion of a cycle and perfect order. Notably, the sexual act indicated by the number seven $(3+4)$ can be achieved only through the union of three (the male principle), and four (the female principle).

On the other hand, Room 237 can refer to the Oedipal conflict. In Danny's mind, the number two may stand for his two parents while the number three to Danny himself and his relation to Jack and Wendy in the nuclear family. This is symbolic of the Oedipal situation with its deep involvement of three persons with one another-Danny, Jack, and Wendy. For Danny, however, his desire is to escape the triadic existence and search for his personal and social identity in individualization. Only through this process, 2 (parents) $\rightarrow 3$ (Oedipal conflict) $\rightarrow 7$ (initiation circle), can Danny complete the separation-initiation-return individualization circle that will lead to his autonomy.

Mirrors are the repositories of unseen psychic spirits (Jones, 1995). People wear a persona to cover their true selves. However, when looking in a mirror, the true self, never shown to the outside world, can be seen. According to Jung (1990), all humans have a repressed alter ego-the shadow or the second self. Humans need to confront the repressed alter ego in order to know themselves though the confrontation is always disagreeable. In The Shining, mirrors are used to show the repressed alter ego of Jack (Brown, 1992; Holland, 1999).

In the scene in which Wendy serves breakfast to Jack while he is lying in the bed, Jack looks at the mirror while eating his breakfast. In the scene in which Danny returns to his room to sleep, Jack is seen staring at himself in the mirror in an ecstasy. In this latter scene, Jack and his mirror image are framed together, revealing the dual nature of Jack's character. The conjunction of both real Jack (the self) and his mirror image (shadow) indicates that both Jacks are equally present and both need to be faced. However, Jack does not want to face his shadow lurking beneath the mirror's surface. He disregards it, not knowing that the whole can be achieved only by balancing his self (ego) and his shadow (alter-ego). Not being able to reach this balance, Jack is overwhelmed by his unconscious. 
Unlike Jack, who cannot face his shadow, Danny uses mirrors as a way to face his unconscious. The word "redrum" is understood only when reflected in a mirror. In mirror-image the word is revealed as "murder," which signifies Danny's use of the mirror to reveal a primal fear (one often found in fairytales): the fear of being annihilated (Kilker, 2006).

In the Oedipal triad, Danny experiences the anxiety of being annihilated, and Jack experiences the anxiety of being overtaken and abandoned. In order to protect himself from being annihilated, Danny creates Tony as a guardian angel to watch over him and to channel his negative feelings about his father into someone, other than himself .

Danny's unconscious is thus symbolized by Tony who acts as a guardian angel to help Danny survive. Jack's unconscious, on the other hand, is symbolized by Lloyd and Grady who are heralds of death (Holland-Toll, 1999). Jack's creativity wanes at the Overlook, and he becomes increasingly jealous of Danny's shining. He becomes obsessed with the idea that Danny's power impedes his own. Thus Jack's jealousy of Danny's shining, as well as his suspicion of an Oedipal desire between Wendy and Danny, arouses Jack's anger and makes him wish unconsciously to get rid of them (Caldwell \& Umland, 1986).

Jack encounters Lloyd in the ballroom and complains about his family. He exclaims, "God, I'd give anything for a drink. I'd give my goddamn soul just for a glass of beer.” After Jack had dislocated Danny's shoulder in a drunken rage, he gave up drinking. His regression into drinking signals a breakdown between his ego and id. This breakdown is shown symbolically when Jack confronts Grady in the red and white restroom of the ballroom. Grady was a previous caretaker of the Overlook Hotel and a man who murdered his own family. Jack speaks of Grady in the past tense, referring to him as a man who "was" the caretaker who "killed" his wife and children and "committed" suicide. Grady, on the other hand, speaks only in the present and future tenses, noting that Jack "is" the caretaker and that he "will always be" the caretaker. The conjunction of past-tense, present-tense, and future-tense actions implies that the presenttense and future-tense actions are doomed to repeat the past-tense actions. From a visual standpoint (Smith, 1997), Jack is forced to encounter the red chaos of his unbridled emotions (id) and the white purity of his conscience (superego). To put the conflict into psychoanalytic terms, the restroom symbolizes a struggle between the turmoil of the red pleasure principle and the formalities of the white reality principle (Franzke, 1989; Freud, 1955; 
Jung, 1990). Only when these two principles coexist harmoniously can autonomy be achieved. Jack's failure is that he cannot face his unconscious self and face his inner chaos. The result is his insanity.

People's anxieties about death, failure, and castration can turn something frightening into something uncanny (Freud, 1958; Hoile, 1984). In The Shining, Kubrick suggests through Jack's present-tense and futuretense actions repeating Grady's past-tense actions that humans are, either consciously or unconsciously, interrelated and involuntarily double and repeat the lives of others (Franzke, 1989; Holland-Toll, 1999). This involuntary repetition of an evil past suggests that the dead are the enemy of those still alive as they attempt to carry them into the world of the dead (Freud, 1958, p. 242). In the Overlook Hotel, the repeating murders, like the recurrent vision of waves of blood, remind the audience that the hotel was built on Indian burial grounds. This act is a symbol of the inherent evil in humans (Holland-Toll, 1999).

In fact, this first evil act in the past becomes inseparable from the repeating violence of the present (Holie, 1984). The hotel owner sacrificed the souls of those buried beneath his building in order to make his fortune; Grady sacrificed his family to correct them when he saw them as being out of line; Jack attempts to sacrifice Wendy and Danny because they, too, are out of line. Both Grady and Jack involuntarily repeat the evil that is part of the past of the hotel. They build authority over their families through violence, not communication.

With this ever-repeating evil, the Overlook Hotel is reminiscent of the haunted houses of fairytales. Like the evil in haunted houses in fairytales, the Overlook Hotel serves as psychic batteries that absorb primitive feelings and emotions, such as rage, hatred, and fear. These psychic batteries are charged with the evil spirits and destructive rage that have been spent there, much as a car battery absorbs an electric charge (Freud, 1958; Magistrale, 1992). When the charge is complete, the Overlook Hotel discharges or delivers its evil energy to the people living in the hotel only to re-absorb the evil once again.

Being charged with evil spirits, the Overlook Hotel becomes symbolic of collective human evil. Not able to recognize the evil in the hotel, Jack is infected with its primitive emotions and transforms into a homicidal maniac who targets his anger at his family. Eventually, he cannot keep himself from performing violent acts because he is "charged" by the evilness in the Overlook Hotel (Holie, 1984). 
The heart of the evilness in the Overlook Hotel is the kitchen. Further, the kitchen is directly paralleled with fairytales when Wendy says that she will "have to leave a trail of bread crumbs every time" she comes in. In fairytales, evil spirits such as witches and wolves find unwanted entrance into a house through the chimney of the kitchen (Bettelheim, 1977). It is after entering the storage room in the kitchen that Jack is infected by the evil of the hotel, and later transforms into an executioner for the evil spirit who feels Jack must correct the behaviors of his family when they are out of line (Walter, 1985).

Unlike Jack, who leads himself into the maze of the kitchen, Danny, however, is not trapped by the mazes. Jack identifies with Grady and Lloyd and is later trapped in the evil history of the Overlook Hotel; Danny refuses to identify with the twin girls who appear to him. He refuses to see himself as a victim and thus manages to complete his individualization development. The girls appear as trickster figures who tempt Danny three times. In the first two temptations, Danny tries to repress the image of the girls because he is anxious about being devoured by the evil spirits they represent. However, in the third temptation, when the girls urge him to "Come play with us," he manages to repudiate the image of the slaughtered bodies of the twin girls by consciously reminding himself that they are not real. By avoiding identifying with the victimized twin sisters, Danny succeeds in using his intelligence and personal integration to listen to his consciousness (ego) and master his unconscious (id) (Caldwell \& Umland, 1986; Holie, 1984).

Jack, on the other hand, completely identifies with Grady, and lets himself be advised to correct his wife and son when they are out of line. While chopping down the bathroom door with an ax, Jack exclaims with a sarcastic smile, "Wendy, I'm home." Based on Freud's theories, "home" can be interpreted as the mother's womb. Moreover, when someone says that a place is homely, it implies that the place is as comfortable as a home, a metaphor for the mother's womb. Notably, when Jack arrives at the hotel, Jack declares that "It's very homely," and he would "like to stay here forever" (Kubrick, 1980). This is indicative of his desire to go back to the maternal womb. But although Jack does indeed go back, it is not to the timeless paradise of pre-birth, but a timeless hell hidden with devil spirits.

When Jack crashes through the bedroom door with his ax, Wendy pushes Danny through a tiny bathroom window into the snowy world outside. The narrow window can be interpreted as an "opening for the 
body," or the birth orifice of females (Jung, 1990). It is after being pushed out of the narrow window, then, that Danny frees himself from maternal bonds and achieves autonomy. Furthermore, if Danny's shining is a symptom of neurosis, then after being pushed out of the narrow window, he can free himself from his childish dependency on his mother. Thus, at this point the voice of Danny's double, Tony, disappears; Danny is able to conquer his neuroses on his own, and can use his wit to save his trapped mother from the big bad wolf (Kilker, 2006). By this point Jack has become irretrievably trapped in the evil of the hotel. This began when he led his family into the maze of the hotel and it was completed when he led himself into the maze of the kitchen where he encountered the heart of evil. Danny, however, is not trapped by the mazes. In fact, as if he knows his father's weakness, he leads him into the maze-like garden. Like the protagonists in the fairytale of Hansel and Gretel, Danny cleverly wipes out his tracks. This signifies Danny's ability to go into the maze but find his own way out. He retraces his steps and thus leaves his father trapped in the maze while he is able to escape it, its evil, and his father's domination (Kast, 1993; Luthi, 1984).

When people are situated in an insecure position, they may withdraw into themselves, or in an extreme situation they may simply wish to return to the mother's belly or die (Freud, 1955). Unlike Danny who can use his wit to save his mother, freeing himself to achieve his autonomy, Jack is trapped in the notion that he is insignificant in the universe, and experiences the anxiety of being overwhelmed and abandoned. The hotel and its mazes show his desire to return to the womb, to be reborn again.

Jack's self-destruction can be interpreted as his inability to succeed in the Oedipal triad and admit that his child will surpass him. He is afraid of being thought worthless by his wife and son, and is trapped in the notion that he is insignificant in the universe. He experiences the anxiety of being overwhelmed and abandoned, and desires to return to the womb to be reborn again.

Unfortunately, this desire makes him vulnerable to the evil spirits in the hotel, and he allows himself to be devoured by his dark side, turning into the big bad wolf.

The image of Jack as the evil animal of so many fairytales is strongest when Jack, armed with an ax, chases after Danny in the maze-like garden. As he moves deeper into the maze, Jack transforms into an animal (id) that is incapable of articulating his feelings, but rather shouts and howls. It is 
reminiscent of the Minotaur, a monster with the body of a human and the head of a beast (Caldwell \& Umland, 1986; Smith, 1997).

As with caves in fairytales, mazes can be interpreted as symbolic of the maternal belly. Entering a cave or a maze can thus be regarded as a regression to the womb (Bettleheim, 1977). Being trapped in the maze, Jack is overwhelmed by his unconscious and regresses into his animal shape - fetus - in the maternal belly. Unlike Danny, who escapes from the maze-like garden and reenters the physical world to complete his "separation-initiation-return" journey to reach autonomy and individualization, Jack is totally defeated by his id. Failing to manage his Oedipal problem, he is trapped in the maze and absorbed by the evil history of the Overlook Hotel.

Though being a father, Jack cannot complete his individualization process through the stay in the Overlook Hotel. Identified with Grady and Lloyd, he is trapped in the evil history of the Overlook Hotel and later is transformed into a homicidal maniac, pouring his anger to his family, Danny and Wendy. Unlike Jack, Danny refuses to identify with the evil history of the hotel and see himself as a victim, hence completing his individualization development and leading to his autonomy.

\section{REFERENCES}

Bettelheim, B. (1977). The uses of enchantment: The meaning and importance of fairy tales. New York: Vantage Books.

Brown, J. (1992). The impossible object: Reflections on The Shining. In J. Orr, \& C. Nicholson (Eds.), Cinema and fiction (pp. 104-121). Edinburgh: Edinburgh.

Caldwell, L. W., \& Umland, S. J. (1986). Come and play with us: The play metaphor in Kubrick's Shining. Literature/Film Quarterly, 14(2), 106-111.

Franzke, E. (1989). Fairy tales in psychotherapy: The creative use of old and new tales. New York: Hogrefe \& Huber Publishers.

Freud, S. (1955). The standard edition of the complete psychological works of Sigmund Freud. (24 vols.). (J. Strachey, Ed., \& Trans.). London: Hogarth.

Freud, S. (1958). The uncanny: On creativity and the unconscious. New York: Harper and Row.

Freud, S. (1999). The interpretation of dreams. Trans. (J. Crick, Trans.). New York: Oxford University Press. 
Hoile, C. (1984). The uncanny and the fairy tale in Kubrick's The Shining. Literature/Film Quarterly, 12, 5-12.

Holland-Toll, L. J. (1999). Bakhtin’s carnival reversed: King’s The Shining as dark carnival. Journal of Popular Culture, 33(2), 131-146.

Jones, S. S. (1995). The fairy tale: The magic mirror of imagination. New York: Twayne Publishers.

Jung, C. G. (1990). Archetype and collective unconscious. London: Routledge.

Kast, K. (1993). Through emotions to maturity: Psychological readings of fairy tales. New York: International Publishing.

Kilker, R. (2006). All roads lead to the abject: The monstrous feminine and gender boundaries in Stanley Kubrick's The Shining. Literature/Film Quarterly, 34(1), 54-63.

King, S. (1977). The shining. New York: Signet.

Kubrick, S. (Director). (1980). The shining. London: Hawk Films.

Luthi, M. (1984). The fairytale as art form and portrait of man. Indiana: Indiana University Press, Bloomington.

Magistrale, T. (Ed.). (1992). The dark descent: Essays defining Stephen's horrorscape. New York: Greenwood.

McGlathery, J. M. (1993). Grimms' fairy tales: A history of criticism on a popular classic. South Carolina: Columbia.

Smith, G. (1997). Real horrorshow: The juxtaposition of subtext, satire, and audience implication in Stanley Kubrick's The Shining. Literature/Film Quarterly, 25(4), 300-306.

Walter, C. T. (1985). Stanley Kubrick's The Shining: A study in the terror of abstraction. Ball State University Forum, 26(3), 21-38.

Zipes, J. (1994). Fairy tales as myths. Kentucky: University of Kentucky. 